\title{
トピックス
}

\section{Head-shaking nystagmus test}

\author{
大木 雅文
}

\section{Head-shaking nystagmus test}

\author{
Masafumi Ohki \\ Department of Otolaryngology, Saitama Medical Center, Saitama Medical University
}

\section{Head-shaking nystagmus とは}

頭部を左右または前後に反復頭振運動をさせる と頭振後に眼振が誘発されることがあり，これは Head-shaking nystagmus（頭振後眼振）と呼ば れ, Vogelが1932年に初めて報告している の後, 1964年に Kamei らが再評価し, 未梢・中 枢前庭機能評価に際して, その有用性を報告して いる ${ }^{2)}$ 。

\section{Head-shaking nystagmus の機序}

Head-shaking nystagmusの機序はまだ不明な 点も多いが, 不均衡な前庭性入力と中枢速度蓄積 機構 (velocity storage) により生じるとされてい $ろ^{3)}$ 。反復頭振運動刺激により, 半規管内の内リ ンパ流動が半規管膨大部のクプラを偏位させ有毛 細胞の神経活動が変化し, Ewald の第 2 法則に従 った前庭入力を生じる。前庭機能障害などによ り, 左右のクプラの有毛細胞の神経活動が不均衡 である場合, 正常側への頭振の際に生じる前庭性 入力の方が前庭機能障害側への頭振による前庭性 入力より大きくなる。この不均衡な前庭性入力は 内側前庭神経核とその交差性線維による中枢速度 蓄積機構 (velocity storage $)^{4)}$ に蓄積され, 反復 頭振運動刺激の停止と共に急速に放出され前庭動 眼反射の経路を通じて眼振を引き起こすとされ る ${ }^{3)}$ 。この眼振が Head-shaking nystagmus と呼ば れる。

埼玉医科大学総合医療センター耳鼻咽喉科

\section{Head-shaking nystagmus test $の$ 手技}

水平方向の Head-shaking nystagmus test は披 検者にフレンツェル眼鏡下または赤外線カメラを 装着させ，検者が被検者の頭部側面を両手で保持 し, 左右各45度の大きさで左右方向に往復 $20 \sim 30$ 回, 毎秒約 2 往復の速さで頭部を振る（図 1 )。 反復頭振運動刺激後, 開眼させ, フレンツェル眼 鏡下または赤外線カメラ下に眼球運動を観察す る。垂直方向の Head-shaking nystagmus は水平 方向と基本的に同じことを, 矢状方向に反復頭振 運動刺激を行う。往復20～30回, 約 2 秒間に 3 往 復の速さで, かつ可能な範囲で大きな振幅で振 $る^{5)}$ 。水平性の Head-shaking nystagmus は単相性 と 2 相性があり, 単相性眼振と 2 相性眼振の第 1 相は通常, 頭振直後より出現し 30 秒以内に消失す る。一側の前庭機能低下を反映することが多いと されている。第 2 相 (逆相) はその後出現するも のである。眼振は頭振後, 潜時をもって出現する ことがあるため, 頭振後 15 秒は観察する。また最 初の眼振終了後少なくとも15秒は第 2 相の出現が ないか確認する必要がある。水平方向の Headshaking nystagmus test の方が, 垂直方向の Headshaking nystagmus testより眼振誘発率が高く,

一般的には水平方向 Head-shaking nystagmus test が行われている。中枢性障害の場合は垂直方 向の Head-shaking nystagmus testにより垂直性 眼振が誘発されることがあるため, 中枢障害を疑 う際には垂直方向 Head-shaking nystagmus test 
も行うのが望ましい。ただし, 頭蓋内の新鮮な器 質的障害を疑う場合や頸椎の異常がある場合は注 意が必要である5)。

\section{Head-shaking nystagmus test $の$ 臨床利用}

水平方向の Head-shaking nystagmus の出現は 前庭機能の左右の不均衡を示唆するため, 未梢前 庭障害患者で出現することが多い（図 2)。 Iwasaki ら，Ohki らは前庭機能障害患者の約40～ 50\%で Head-shaking nystagmus が検出できたと

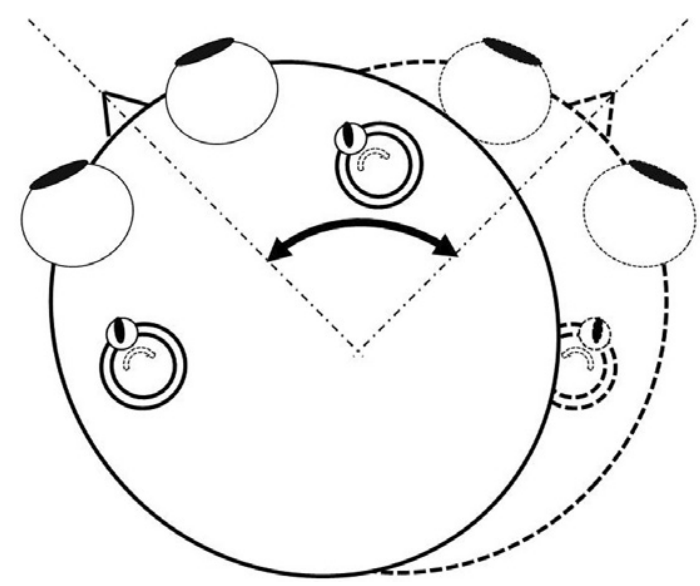

図 1 水平方向 Head-shaking nystagmus test では 検者は患者の頭部を側方から保持し，左右方 向に往復20３0回，左右各45度の大きさで毎 秒約 2 往復の速さで反復頭振運動刺激を行 j。
報告している ${ }^{677)}$ 。一側の半規管機能低下がある場 合に Head-shaking nystagmus が誘発されること が多く, Ohki らは50\%以上の半規管機能低下を 呈する患者の $65 \%$ で Head-shaking nystagmus の 出現を認めている7)。このため, 半規管機能低下 の検出するスクリーニング検査の役割も担うと思 われる。Iwasaki らの報告によれば Head-shaking nystagmus testによる $20 \%$ 以上の半規管機能低下 の検出は感度 $66 \%$, 特異度 $77 \%$ である ${ }^{6}$ 。 Headshaking nystagmus の方向は健側向きあるいは患 側向きが出現することが多い。Iwasaki らは一側 前庭機能低下を認めた患者の $84 \% て ゙$ 健側向 き，13\%で患側向きの Head-shaking nystagmus が出現したと報告している ${ }^{6)}$ 。末梢前庭障害患者 では中枢前庭障害やメニエール病を除くと，通 常, 健側向きの Head-shaking nystagmus が出現 し，患側の推定の助けとなる ${ }^{8)}$ 。

疾患による誘発率や眼振の方向の違いが報告さ れており, Kim らは前庭神経炎患者の $100 \%$, メ ニエール病の $68 \%, \mathrm{BPPV}$ 患者の $22 \%$ で誘発され たとしている9”。殊にメニエール病では患側向き の Head-shaking nystagmus が誘発されることが しばしばみられる の Head-shaking nystagmus が出現し，間歇期で は健側向きの Head-shaking nystagmus が誘発さ れやすいと報告している ${ }^{11)}$ 。

中枢前庭障害においても Head-shaking nystagmusが出現することがある。Huhらの報告で

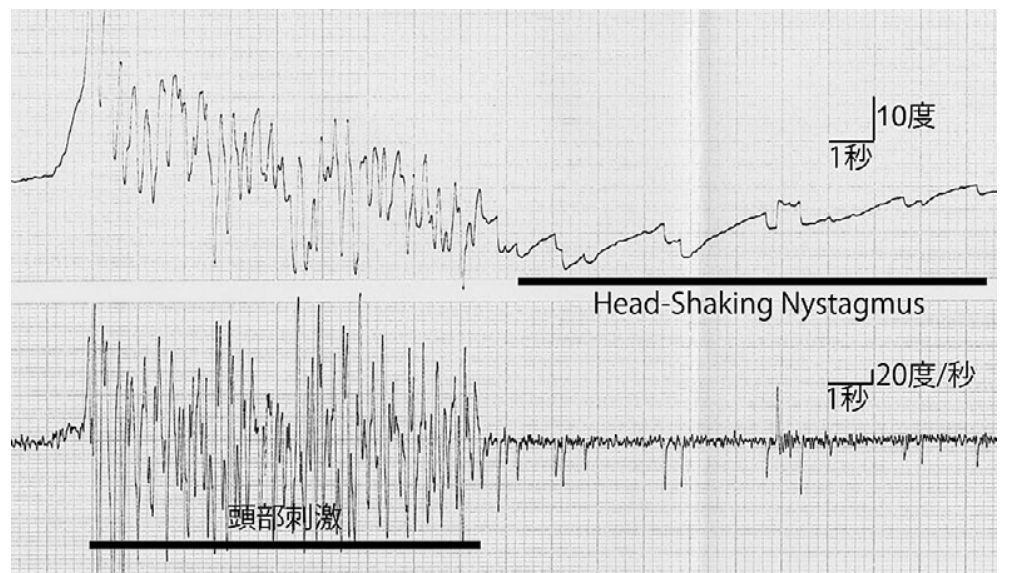

図2 66歳, 女性。右メニエール病患者(右半規管機能低下51\%)における Head -shaking nystagmus。反復頭振運動刺激後に左向き眼振が誘発された。 
は, 前下小脳動脈領域梗塞の83\%で Head-shaking nystagmus が誘発され，その向きは多くが健側向 きであるが，中枢障害を示唆する垂直成分が含ま れることがあることや半規管機能低下のみられる 患側方向への Head-shaking nystagmus が誘発さ れることもあり，末梢前庭障害と中枢前庭障害の 両者の特徵が混合した眼振を呈し, 中枢障害を示 唆する垂直成分に関しては片葉障害の関与を指摘 している ${ }^{12)}$ 。後下小脳動脈領域梗塞でも Headshaking nystagmus が誘発されることが多く, 眼 振の向きは患側向きや下眼瞼向きが多いと報告さ れている ${ }^{13)}$ 15)。小脳, 特に小脳虫部・扁桃のプル キンエ細胞からの中枢速度蓄積機構への抑制性投 射の障害などが原因と考えられる ${ }^{13) ~ 15) 。 ~}$

\section{Head-shaking nystagmus test $の$ 利点}

前庭機能検査には注視眼振・頭位眼振・頭位変 換眼振検査, ENG 検査によるカロリックテスト, 前庭誘発筋電位検査 (VEMP), head impulse test などがあるが，外来ですべての患者にこれらの検 查を網羅することは現実的ではない。めまい症状 を呈する疾患は前庭障害以外にも中枢病変, 自律 神経障害, 精神疾患などさまざまな疾患が含まれ ている。前庭機能障害を有する場合, 前庭動眼反 射経路の異常により眼振が出現することが多く, 眼振の検出により，診断に一歩近づくことにな る。一側の急性前庭障害は自発眼振を呈すること が多いが, 時間が経過すれば, 前庭代償により自 発眼振は消失してしまう。この前庭代償後の状態 では注視眼振・頭位眼振・頭位変換眼振検査では 前庭機能障害は検出できず, 診断のためには ENG 検査によるカロリックテスト, VEMP, head impulse test など行う必要があるが, 検査の手 間・時間・機器の購入の必要性などの課題が残 る。Head-shaking nystagmus test はフレンツェ ル眼鏡下または赤外線カメラがあればすぐ行える 検査であり, 通常の外来やベットサイドで簡便に 検査可能である。

\section{文献}

1) Vogel K: Uber den Nachweis des latenten Spontannystagmus. Z Laryngol Rhinol 22: 202-207, 1932

2 ) Kamei T, Kimura K, Kaneko H, et al.: Revaluation of the head-shaking test as a method of nystagmus provocation. I: Its nystagmus- eliciting effect. Jpn J Otol 67: 1530-1534, 1964

3 ) Hain TC, Fetter M, Zee DS: Head-shaking nystagmus in patients with unilateral peripheral vestibular lesions. Am J Otolaryngol 8: 36-47, 1987

4) Katz E, Vianney de Jong JM, BuettnerEnnever J, et al.: Effects of midline medullary lesions on velocity storage and the vestibuloocular reflex. Exp Brain Res 87: 505-520, 1991

5 ）亀井民雄 : 検査の実際 II（迷路刺激検査）頭 振り刺激検査. イラスト めまいの検査. 日 本平衡神経科学会編, 80-81頁, 診断と治療 社, 東京, 1996

6 ) Iwasaki S, Ito K, Abbey K, et al.: Prediction of canal paresis using Head-shaking nystagmus test. Acta Otolaryngol 124: 803-806, 2004

7 ) Ohki M, Murofushi T, Nakahara H, et al.: Vibration-induced nystagmus in patients with vestibular disorders. Otolaryngol Head Neck Surg 129: 255-258, 2003

8 ) Takahashi S, Fetter M, Koenig E, et al.: The clinical significance of Head-shaking nystagmus in the dizzy patient. Acta Otolaryngol 109: 8-14, 1990

9 ) Kim MB, Huh SH, Ban JH: Diversity of head shaking nystagmus in peripheral vestibular disease. Otol Neurotol 33: 634-639, 2012

10) Marques PS, Perez-Fernandez N: Bedside vestibular examination in patients with unilateral definite Ménière's disease. Acta Otolaryngol 132: 498-504, 2012

11) Lee SU, Kee HJ, Sheen SS, et al.: Headshaking and Vibration-induced Nystagmus During and Between the Attacks of Unilateral Ménière's Disease. Otol Neurotol 36: 865872, 2015

12) Huh YE, Koo JW, Lee H, et al.: Head-shaking aids in the diagnosis of acute audiovestibular loss due to anterior inferior cerebellar artery infarction. Audiol Neurootol 18: 114-124, 2013 
13) Huh YE, Kim JS: Patterns of spontaneous and head-shaking nystagmus in cerebellar infarction: imaging correlations. Brain 134: 3662-3671, 2011

14) Choi KD, Kim JS: Head-shaking nystagmus in central vestibulopathies. Ann N Y Acad Sci 1164: 338-343, 2009
15) Choi KD, Oh SY, Park SH, et al.: Headshaking nystagmus in lateral medullary infarction: patterns and possible mechanisms. Neurology 68: 1337-1344, 2007

利益相反に該当する事項はない。 